\title{
Towards a semiotic theory of hegemony: Naming as hegemonic operation in Lotman and Laclau
}

\author{
Peeter Selg, Andreas Ventsel \\ Institute of Political Science and Public Administration, Tallinn University \\ 25 Narva St, 10120 Tallinn, Estonia \\ e-mail: pselg@tlu.ee; ${ }^{1}$ \\ Department of Semiotics, University of Tartu \\ 78 Tiigi St. 50410 Tartu, Estonia \\ e-mail: andreas.ventsel@ut.ee
}

\begin{abstract}
The article concentrates on the possibilities of bringing into dialogue two different theoretical frameworks for conceptualising social reality and power: those proposed by Ernesto Laclau, one of the leading current theorists of hegemony, and Juri Lotman, a path breaking cultural theorist. We argue that these two models contain several concepts that despite their different verbal expressions play exactly the same functional role in both theories. In this article, however, we put special emphasis on the problem of naming for both theorists. We propose to see naming as one of the central translating strategies in the politico-hegemonic discourse. Our main thesis is that through substituting some central categories of Laclau's theory with those of Lotman's, it is possible to develop a model of hegemony that is a better tool for empirical study of power relations in given social formations than the model proposed by Laclau, who in his later works tends more and more to ground it in psychoanalytic ontology.
\end{abstract}

Also: Faculty of Humanities, Tallinn University of Technology; 21 J. Sütiste St, 13419 Tallinn, Estonia; e-mail: peeter.selg@ttu.ee 


\section{Introduction}

The term "political semiotics" finds more and more usage among scholars in the field of social sciences. Yet seldom if ever does it refer to a discipline with clearly defined aims and scope. Rather it is a somewhat vaguely applied synonym for expressions like "political signs" or "political images" etc. Our purpose in this article is to address the problem of what would political semiotics as a discipline require. We are of course well aware that for a discipline to arise it takes much more than a single article, monograph or conference. Providing an elaborated conception of that discipline (or even some "grounding principles" for such an elaboration) is not the task we set for ourselves. Instead we try to make a contribution to the dialogue between political science and semiotics by way of introducing Juri Lotman's categories from theory of culture to one of the most advanced conceptions of hegemony in contemporary political theory the one proposed by Ernesto Laclau.

The general problem our article deals with is that of political power. We strive to give some hopefully fruitful hints for dealing with this issue from the semiotic point of view. Political power has gained much theoretical and methodological attention among disciplines such as philosophy, sociology and political science, but has occurred somewhat sporadically along the field of semiotics. The theses we propose are very much preliminary in nature - they form no coherent research report or conception, but are more like glimpses of the future. Our theses stem largely from what we see as a set of apparent theoretical congenialities between Juri Lotman, a semiotician, whose interests moved more and more towards issues usually governed by social or political theory, ${ }^{2}$ and Ernesto Laclau, a political theorist whose conception of hegemony has had several stages of development ranging from Marxist tradition to post-structuralist discourse theory.

Our general idea is that the theoretical frameworks or metalanguages that these two eminent thinkers propose for conceptualizing social reality contain several concepts that despite their different verbal expressions play exactly the same functional role in both

2 It is interesting to refer in this connection to a quite recent volume of essays that is largely dedicated to the theoretical resources that Lotman's semiotics of culture provides for conceptualizing power, hegemony and social reality as such (see Schönle 2006). 
theories. By this we mean that the central categories of each theory can be substituted with each other without losing any theoretical coherence or epistemological value of either of the theories in question. For example, if we substitute the vocabulary of "logic of equivalence" in Laclau with Lotman's idea of "continuous coding" (see below), we would not lose the point that Laclau is making by his theory. And the reason is that these two notions bear the same functional role in each theory. Of course, which conceptual matchings are there between those two approaches, is a matter of analysis, and this article tries to enlighten some of its aspects. But an important thing to stress in this connection is that despite their resemblances, the two theories have important differences that make mutual combination between these approaches a fruitful undertaking. Otherwise we would just reiterate the same points with different words.

In this article, however, we chose only to focus on Laclau's conception of "empty signifier" as a name that functions as a precarious and hegemonic ground for a discourse. Our intention is to complement this conception with Lotman's fundamental idea of rhetorical translation between discrete and non-discrete coding systems and to view naming as one of the translation strategies through which hegemonic relations are established. This way we can avoid the psychoanalytically oriented conception of 'radical investment' that is the basis of Laclau's conception of naming (see Laclau 2005a: 112-117), and substitute problems of affect, desire, and drive with the problems of translation. And our main thesis is that through this substitution it is possible to develop a model of hegemony that is a better tool for empirical study of power relations in given social formations than the model proposed by Laclau, who in his later works tends more and more to ground it in psychoanalytic ontology.

The first task for us, therefore, is to give a brief sketch of the theoretical steps that lead Laclau to that direction. After that we can introduce some basic ideas of Lotman and bring them into dialogue with Laclau. In this article we dedicate a little more room for discussion on Laclau than to that on Lotman, because the latter's positions are assumingly better known among semioticians than are Laclau's ideas. 


\section{Laclau's conception of the political: some background remarks}

What are Laclau's theses concerning political power? Addressing this question calls first for a very brief sketch of Laclau's major theoretical affinities with a family of political thinkers. The most apparent of them is, of course, Antonio Gramsci, a Marxist theorist and political activist. His main contribution to political theory consists in elaborating a concept of hegemony as a form of power that is very different from mere force, coercion or domination (dominio) and depends largely on the so called spontaneous consent of those who are in the subordinated position. From the perspective of those groups who subordinate others in a society, we can say with Gramsci that

The supremacy of a social group is manifested in two ways: as "domination" and as "intellectual and moral leadership". A social group is dominant over those antagonistic groups it wants to "liquidate" or to subdue even with armed force, and it is leading with respect to those groups that are associated and allied with it. (Gramsci 1975: 2010, quoted in Fontana 1993: 141)

The latter form of supremacy is, of course, what Gramsci calls "hegemony". It should be noted, however that the terms "alliance" and "association" he uses when writing about "hegemony" refer "to a system of reciprocal links and relations whose common elements are consent and persuasion [...] In other words, the "alliance" is based on mutuality of interests and an affinity of values" (Fontana 1993: 141). So we can agree with Steedman when he argues, using more traditional vocabulary for political scientists, that, when there is public or state control "the control must also be seen as legitimate. Gramsci's hegemony is what the ruling class achieves when it can secure popular consent for the state's use of coercion" (Steedman 2006: 139). But we have to add that this hegemony is not purely a result of propaganda or brainwashing, nor is it just a matter of rational selfinterest or values, but has to do with everything in this list. This is what opens up in Gramsci the possibility of conceiving a relation of hegemony as a certain type of formation of contingent meanings or discourses in culture and society. Gramsci, however, did not take this step - at least according to some theorists, Laclau among them.

Despite many advantages of Gramsci's approach, the main shortcoming for Laclau is his tendency to ascribe the ultimate unifying 
power in hegemonic formations to an economically defined fundamental class (Dallmayr 2004: 38). That is the main remnant of essentialism in Gramsci for Laclau and his coauthors (Laclau, Mouffe 1985: 137-138). So, one of the aims of Laclau's theorizing of hegemony is to totally reject any ontological class unity and to acknowledge on the theoretical level the proliferation of very different and often incommensurable political struggles in the late capitalist society. That is one set of theoretical steps taken by Laclau in his conception of hegemony. Following his advice, we could call it a movement from Marxism to post-Marxism (Laclau, Mouffe 2001: ix).

But another very important family of steps needs to be highlighted in this conception. And that we could call: the movement towards a notion of discourse as the primary terrain of objectivity, hegemonic and power relations. Important parallels can first be drawn with Michel Foucault whose emphasis on the positive or productive aspects of power, especially its ability to produce discourse has reoriented the whole corpus of power studies. "What makes power hold good," for Foucault, "what makes it accepted, is simply the fact that it doesn't only weigh on us as a force that says no, but it traverses and produces things, it induces pleasure, forms knowledge, produces discourse" (Foucault 1980: 119 — italics added). The general reorientation in the conception of power is that "It needs to be considered as a productive network which runs through the whole social body, much more than as a negative instance whose function is repression" (Foucault 1980: 119 - italics added). The general methodological precaution that follows from this reorientation is

\begin{abstract}
that we should direct our researches on the nature of power not towards the juridical edifice of sovereignty, the State apparatuses and the ideologies which accompany them, but towards forms of subjection and the inflections and utilizations of their localized systems, and towards strategic apparatuses. We must eschew the model of Leviathan in the study of Power. (Foucault 1980: 102)
\end{abstract}

The old questions like "who has power?" or "who is repressed by power?" make no sense anymore. The focus of studying political power moves away from the sovereign forms of power like state or administrative apparatuses and the hitherto systematically concealed forms of power - especially the power of discourses - enter the center of attention in the social sciences. 
This, of course, means disavowing the liberal tradition of conceptualizing power that informs the lion's share of current political science. This is a tradition that starts with philosophies of Thomas Hobbes and John Locke and moves through several quasi-philosophical steps to the sociology of Max Weber, and through his influence it becomes a common sense view among the political scientists in the United States. And the main message of the liberalist tradition concerning power is something like this: power is ontologically speaking - a thing. It is something that can be possessed or distributed. But what kind of thing is it? A thing that can be used to make somebody do something that he would not otherwise do. In other words: power is a means of repression. ${ }^{3}$

One of the indications of how influential this liberalist tradition is, is the fact that even the most well-known critics of liberalist political philosophy - most notably the Marxists and the so called communitarians - use the same vocabulary when it comes to the notion of power. Even Louis Althusser, the most eminent Marxist theorist of our time, despite his theoretical attempt to ease up the determinate nature of the relations between the basis and superstructure, had to concede that to his knowledge, "no class can hold State power over a long period without at the same time exercising its hegemony over and in the State Ideological Apparatuses" (Althusser 1993: 20, italics by the author). As for the "communitarians" - a family of political theorists who oppose the notion of abstract or "unencumbered" self (see Sandel 1998) that supposedly underlies the liberalist conception of society - we can cite Michael Walzer, the most quoted among them, as a way of illustrating their vocabulary for grasping power. "Politics is always the most direct path to dominance," he indicates in his book Spheres of Justice, and continues: "and political power [...] is probably the most important, and certainly the most dangerous good in human history" (Walzer 1984:

3 It should be noted that the liberal tradition has entertained conceptions of "soft power", "power of non-decision" or of "agenda-setting" that purport to indicate the alternative forms of power. Though this makes the liberal tradition seem more ambivalent on this question, we believe that these notions of power are nevertheless reducible to the old question of who gets whom to do what the latter would not otherwise do. In other words, they are reducible to the problem of repression. 
15 , italics added). And the talk of power as some sort of "good" is very extensive in this classic book.

Now, this is the notion of power that we have to dismiss if we take seriously the methodological instructions of Foucault. Laclau certainly agrees with Foucault in this respect. But what is problematic for him is Foucault's conception of discourse. For Laclau the discourse is not an object among many, as it is for Foucault (see Foucault 1969; 1984), but the primary terrain of objectivity as such (Laclau 2005a: 68). Laclau refers to Wittgenstein's idea of a 'language game' (see Laclau, Mouffe 1985: 108; Laclau 2005a: 106) and Jacques Derrida's notion of 'undecidability' (see Laclau, Mouffe 2001: xi; cf. Norval 2004: 142) when he characterizes his concept of discourse.

For Laclau, nothing is constituted outside the discourse. Yet this has nothing to do with the debate between realists and idealists. Laclau does not deny that earthquakes and other physical phenomena exist. But whether an earthquake is constituted in terms of the "wrath of God" or in terms of "natural disaster" depends on discursive structurations (Laclau, Mouffe 1985: 108).

So the problem of the constitution of social and political reality becomes for Laclau the problem of the constitution of discourse. We concentrate on the general logic of discourse that he proposes in terms of the Saussurean idea that a signifying system or discourse is a system of differences, and try to sketch out the main ways in which he complements this idea in terms of 'empty signifiers' and 'naming'.

\section{Laclau's concepts of discourse, hegemony and naming}

For Laclau, hegemony is to be understood only on the terrain of discourse: a hegemonic relation is a certain kind of articulation of meanings, namely an articulation that takes place "in a field crisscrossed by antagonisms and therefore suppose[s] phenomena of equivalence and frontier effects" (Laclau, Mouffe 1985: 135-136). This articulation requires that a particular difference loses its particularity and becomes a universal representative of the signifying system as a whole. Why is this kind of representation needed at all? Because through that a closure for that system is provided. Since every system of signification is essentially differential, its closure is the precondition of signification being possible at all (Laclau 1996a: 
37). But any closure requires the establishment of limits, and no limit can be drawn without, simultaneously, positing what is beyond it.

But how can you posit what is beyond the limits of the system of all differences? Laclau's answer is: only through radical or antagonistic exclusion (Laclau 1996a: 37). To put it in more simple terms: you have to exclude "them" radically or antagonistically in order to fully form "us" as a coherent system. For example: "it is through the demonization of a section of the population that a society reaches a sense of its own cohesion" (Laclau 2005a: 70). But this exclusion operates through two contradictory logics: on the one hand it makes possible the system of differences as a coherent totality; but, on the other hand, vis-à-vis the excluded element, the differences that now form a totality are no longer merely different but also equivalent to each other. To put it another way, their identity that is based on their more or less clear difference from each other tends to be corrupted or subverted by their being also equivalent to each other (Laclau 2005a: 70).

This insurmountable tension between the logic of difference and that of equivalence is unavoidable in the constitution of every discourse. But a very important conclusion from this tension is that discourse or systemic totality of differences is an object that is, at the same time, impossible and necessary. First it is impossible, because there cannot be a final victory of one logic over the other: purely differential discourse would be just meaningless noise or "discourse of the psychotic" (Laclau, Mouffe 1985: 112); and purely equivalential discourse would be just silence. And since tension between those logics is insurmountable, there is no literal object corresponding to a discourse. You cannot recognize the "True" meanings. But the totality of discourse is not only an impossible object, it is also a necessary one: it has to be created because without that object there would be no signification whatsoever. And this in turn implies that "Any 'closure' is necessarily tropological. This means that those discursive forms that construct a horizon of all possible representation [i. e. signification] within a certain context, which establish the limits of what is 'sayable' are going to be necessarily figurative" (Laclau 2006: 114).

And in explaining this logic of figural construction, Laclau coins the category of "empty signifier" (Laclau 1996a: 36-46). The idea is roughly this: in the formation of discourse the differences lose their identity based on differentiality — in other words: the signifiers that 
form the discourse tend to get emptier and emptier from the point of view of their specific meaning. Consider the signifier "Bronze soldier" or "Bronze night". Its meaning is far less specific at the end of the 2007 than it was a year earlier. Now, this emptying of the signifier takes place through proliferation of different meanings that are attributed to it (cf. Laclau 1996b). But some signifiers tend to get emptier than others. Of course, in practice no signifier can lose its differential meaning altogether, yet Laclau's idea is that the one that does it the most - the so called "empty signifier" - can also, in some circumstances, represent the discourse as a whole and incarnate the totality of the whole system of differences. Which of the signifiers assumes this function, is contingent in the sense that it cannot be determined a priori, but is constituted through hegemonic operation. If it could be determined a priori, the relation between the empty signifier and all the other differences would be a conceptual relation: a relation where the empty signifier would express a common core of all the particular differences belonging to the discourse. But that is exactly what Laclau denies (see Laclau 2006: 108-109). The relationship between the empty signifier and the discourse as a totality is the relationship between a name and an object (Laclau 2006: 109).

So, the problem of naming is at the center of his theory of discourse and hegemony. Through the act of naming the hegemonic relations are established. But how are names and objects related to each other? Laclau takes here a radically antidescriptivist stance (Laclau 2005a: 101-110; Laclau 2006: 109). Antidescriptivism as it stems from the works of Saul Kripke holds that naming does not involve any conceptual mediation but is a primary baptism through which a name is assigned to an object (see Kripke 1980). But Laclau with his references to Slavoj Žižek (1989) goes even further and asserts that the object is not something pre-given, not something that a name can be assigned to. Rather the unity or identity of the object is the result of naming it. Objects are (so to speak) created through naming. The name is the ground for the thing - not the other way round!

4 "The Bronze Night" (Estonian: pronksöö), also known as the April unrest (27-29 April, 2007), refers to the riots and controversy surrounding the 2007 relocation of the "Bronze Soldier", the Soviet World War II memorial in Tallinn, Estonia. 
This means that the study of naming strategies is of utmost importance for political analysis. For example: names like "Bronze night" and "Bronze Soldier", "war against terror" or "struggle against fascism" function as grounds for certain political discourses - not just as some ancillary labels. They, of course, change the differential nature of signifiers that might end up being part of the corresponding discourses.

But a very important question arises concerning this logic of discourse: what are the forces behind these operations that enable naming to be the ground for discourse? And this is the point where our view starts to distance from Laclau's answer, which draws mostly from Lacanian psychoanalytic conceptions of affect, desire and drive. We do not think psychoanalytic approach to be illegitimate in itself; in fact we even believe that it is a coherent general speculative ontology. But our aims are more empirically oriented. That is why we believe that we should dismiss the vocabulary of affect, desire and drive from the model of hegemony, and substitute it with Lotman's cultural semiotic vocabulary of translation and bilingualism.

\section{Lotman's ontological background}

According to Lotman it is characteristic to all thinking mechanisms starting from the structure of the brain to the organization of culture in all its levels - that they are heterogeneously structured. Every meaningful structure consists "of (minimally) two semiotic mechanisms (languages), which are mutually untranslatable and yet similar to each other, since each models, with its own means, the same extrasemiotic reality", (Lotman 2004f: 641) Therefore, every meaningful totality (Lotman's text, Laclau's discourse) is at least bilingual and this also implies that semiotic meanings do not get their full constitution through correspondence to some monolingually graspable "reality".

5 “[...] состоящую (минимально) из двух семиотических механизмов (языков), находящихся в отношении взаимной непереводимости и одновременно подобных друг другу, поскольку каждый своими средствами моделирует одну и ту же внесемиотическую реальность." 
Lotman speaks about discrete and non-discrete (or continuous) coding systems. According to him, the mutual untranslatability of those coding systems is due to their fundamentally different structuring principles. In a discrete system, "the basic bearer of meaning is the segment (= sign), while the text or the chain of segments (=text) is secondary, its meaning being derived from the meanings of the signs" (Lotman 2001: 36). In the discrete coding systems the signs are linked to signs. Linear, causal, logical or chronological sequences characterize texts of this type (Lotman 2004d: 572).

In the continual (or non-discrete) systems, the primary bearer of meaning is the text "that does not dissolve into signs, but is itself a sign or isomorphic to a sign. Here, not the rules of linking signs are active, but the rhythm and symmetry (or arrhythmia and asymmetry, respectively)" (Lotman 2004d: 577). The sign is transformed into its other manifestations or becomes equivalent to the corresponding blur of meaning on some other level. Phenomena that appear different gain ability to become equivalent; various analogies, homomorphisms and isomorphisms become possible that are characteristic to poetic texts and partly also to mathematic and philosophical texts (Lotman 2004d: 572). Using Jakobson's distinction we could say that in the nondiscrete linkage the paradigmatic pole of language prevails, and in the case of discrete linkage the same holds for syntagmatic pole (Jakobson 1971 [1956]: 239-259).

And here a problem arises: how is this antagonism or tension between the two types of coding systems (temporarily) overcome? In fact the situation is somewhat paradoxical. On the one hand, these two languages are mutually untranslatable. Yet, on the other hand, this bilingual antagonism is constitutive (as is the tension between the logic of difference and that of equivalence in the formation of a discourse in Laclau's sense), because bilingualism is the condition for any thinking structure. According to Lotman this "minimal structure contains a third component: a block of contingent equivalences, a

\footnotetext{
6 “который не распадается на знаки, а сам является знаком или изоморфен знаку. Здесь активны не правила соединения знаков, а ритм и симметрия (соответственно аритмия и асимметрия).”
} 
metaphorogenous device that makes possible operations of translation in the conditions of untranslatability"7 (Lotman 2004f: 641).

This mechanism of rhetorical translation integrates the antithetic semiotic structures (the discrete and continuous coding systems) into a unified whole. This unity is necessary for translation to occur and produce positive results, despite the apparent impossibility of any translation (Lotman 2004d: 573). As an elementary condition for semiotic communication, these antithetic tendencies have to disappear in a unified structural totality. Otherwise, any positive meaninggeneration would be impossible. And it is important to notice that it is a two-way (and simultaneous) movement: the continuous text (= sign) is translated by way of setting the discrete units into regular sequences, and the discrete sequences can also be conveyed through continuous texts (Lotman 2004e).

The function of Lotman's mechanism of rhetorical translation is analogous to the one attributed to empty signifier in Laclau's conception: it links the different signifiers into a chain of equivalence. And through that operation the signifiers lose their differential identity and become dominated by the logic of equivalence. Using Lotman's vocabulary for making the same point, we could say that in the political discourse there prevails the non-discrete strategy of translation. It means that discrete and clearly differentiated signs are translated into non-discrete totality. "The main feature of such a world is universal resemblance of everything to everything; the main organizing structural relation that of homomorphism" (Lotman 2004d: 570). This continuous translating strategy "makes one see manifestations of the One phenomenon in the various phenomena of the real world, and observe the One Object behind the diversity of objects of the same type ${ }^{\text {،9 }}$ (Lotman 2004d: 571).

\footnotetext{
7 “Минимальная структура включает в себя и третий элемент: блок условных эквивалентностей, метафорогенное устройство, позволяющее осуществлять операцию перевода в ситуации непереводимости."

8 "Универсальным законом такого мира является подобие всего всему, основное организующее структурное отношение - отношение гомеоморфизма."

9 “"заставляет видеть в разнообразных явлениях реального мира знаки Одного явления, а во всем разнообразии объектов одного класса просматривать Единый Объект."
} 
Yet one question concerning this strategy still remains unanswered: in what way is this One all encompassing phenomenon represented? In other words, the question is: through which act is the discourse closed as a meaning-bearing totality? This problem leads us directly to Lotman's semiotic concept of naming.

\section{Lotman on naming as a translating strategy}

As is well known, Lotman's answer to the previously posed question is: naming. As soon as the outside world (and that can also be a world that is coded in some other language) is set forth, it is also named, in other words: it is semiotized at least on the surface level (Lotman 2004f: 646).

The pure act of naming (uttering the words "Bronze Night", for example) is discrete in nature. But the meaning of the name can function as a representation of a continuous totality or in the extreme case - it can become that totality. This extreme case, as is observed by Lotman, is the logic of mythological naming or identification: "Mythological identification is in principle non-textual in character, emerging from the inseparability of the name and object. What may be at stake in such cases is not substitution of equivalent names, but transformation of the object itself" ${ }^{10}$ (Lotman 2004c: 541).

In Laclau's sense it would be a case of not just equivalence between the name and the object it names - but one of identity. In such a case, the altering of the name would imply altering the object that is named. The name "Stalin" in the Soviet Union of 1940s did not just stand for the "Soviet people" — in the official discourse, it was the Soviet people.

At the other extreme we could imagine the act of naming a completely discrete unit. That would be a completely conventional naming. In that case no transformation takes place in the object when its name is changed into something else.

\footnotetext{
10 “Мифологическое отождествление имеет принципиально внетекстовый характер, вырастая на основе неотделимости названия от вещи. При этом речь может идти не о замене эквивалентных названий, а о трансформации самого объекта.”
} 
In neither of the extremes is politics or hegemony possible, because "We have an end of politics when the community conceived as a totality [the object], and the will representing that totality [the name], become indistinguishable from each other. In that case [...] politics is replaced by administration and the traces of social division disappear" (Laclau 2005b: 48). And "the asymmetry between community as a whole and collective wills is the source of that exhilarating game that we call politics, from which we find our limits but also our possibilities" (Laclau 2005b: 49).

\section{Conclusion: Laclau and Lotman in dialogue}

Let us try to summarize our discussion. We have tried to show that the political discourse is always constructed as a bilingual system. Its main specificity consists in the tendency towards translating discrete elements into a non-discrete totality in the Lotmanian sense or difference into the chain of equivalence in the Laclaudian sense. The main operation that provides the closure of discourse is that of naming. And every closure is more or less hegemonic depending on the degree to which the name functions as the ground for continuity.

And we can combine Laclau's insights on hegemony as an act of grounding a unity between differences through naming with Lotman's insights on mythological naming through which the name and the thing that is named have a tendency to become indistinguishable. As a way of illustrating this point with concrete examples, we could indicate the proliferation of expressions like "accused of organizing the Bronze night" or "during the Bronze night" etc in the current Estonian mass media. The "Bronze night" is not a conventional name for certain events, it tends to become more and more inseparable from the object it names (no matter how fictitious or abstract that object might be). And this means that the Estonian media has a tendency towards the prevalence of mythological-continuous consciousness over the logical-discrete one. But we can problematize the name "Bronze night" itself and think of alternative names. If the prevalent name for the events of April 26-27 was, for example, "The Tallinn spring" or just "The April riots" the discursive articulation of those 
events would be of very different sort. In other words the meaning of those events would be very different. ${ }^{11}$

And finally we arrive directly at the tasks for empirical researchers. For Juri Lotman, different tendencies towards discreteness or non-discreteness form the ground for a typology of cultures ${ }^{12}$. Through a combination of Lotman's work with the theoretical framework developed by Laclau and others, an immensely rich typology for empirical studies of political communication opens up. All those possibilities need theoretical as well as empirical consideration. And this is the task we intend to engage with in our future work. ${ }^{13}$

\section{References}

Althusser, Louis 1993 [1970]. Ideology and ideological state apparatuses (Notes towards an investigation). In: Althusser, Louis, Essays on Ideology. London: Verso, 1-61.

Dallmayr, Fred 2004. Laclau and hegemony: some (post) Hegelian caveats. In: Critchley, Simon; Marchart, Oliver (eds.), Laclau: a Critical Reader. London: Routledge, 35-53.

Fontana, Benedetto 1993. Hegemony and Power: On the Relation Between Gramsci and Machiavelli. Minneapolis, London: University of Minnesota Press.

Foucault, Michel 1969. L'archelogie de savoir. Paris: Gallimard.

- 1980. Power/Knowledge: Selected Interviews and Other Writings 1972-1977. [Ed. and transl. Colin Gordon] New York: Pantheon.

- 1984. Histoire de la sexualité, vol. III. Le souci de soi. Paris: Gallimard.

Gramsci, Antonio 1975. Quaderni del carcere, vol. 3. [Critical edition of the Gramsci Institute. Edited by Valentino Gerratana.] Turin: Einaudi.

Jakobson, Roman 1971 [1956]. Two aspects of language and two types of aphasic disturbances. Selected Writings II. The Hague: Mouton, 239-259.

Kripke, Saul 1980. Naming and Necessity. Cambridge: Harvard University Press. Laclau, Ernesto 1996a. Emancipation(s). London: Verso.

11 We can also indicate to the fact that the name "The Prague Spring" was used only in the Western media and among dissidents of the Eastern block. In the official discourse of Czechoslovakia and other Warsaw Pact countries it had no usage whatsoever.

12 Cf. Lotman 2004a, 2004b, etc.

13 The article is based on our paper presented at the conference Naming in Text, Naming in Culture held at the University of Tartu on December 14-15, 2007. This research is a part of ETF6484 "Nomination and Anonymity in Culture" and of the Centre of Excellence in Cultural Theory. 
- 1996b. The death and resurrection of the theory of ideology. Journal of Political Ideologies 1(3): 201-220.

- 2005a. On Populist Reason. London, New York: Verso.

- 2005b. Populism: What's in a name? In: Panizza, Francisco (ed.), Populism and The Mirror of Democracy. New York: Verso, 32-49.

- 2006. Ideology and post-Marxism. Journal of Political Ideologies 11(2): 103114.

Laclau, Ernesto; Mouffe, Chantal 1985. Hegemony and Socialist Strategy: Towards a Radical Democratic Politics. London: Verso.

- 2001. Preface to the second edition. In: Hegemony and Socialist Strategy: Towards a Radical Democratic Politics. London: Verso, vii-xx.

Lotman, Juri 2001. Universe of the Mind: A Semiotic Theory of Culture. London: I. B. Tauris \& Co. Ltd.

- 2004а. = Лотман, Ю. М., Проблема знака и знаковой системы и типология русской культуры XI-XIX веков. Семиосфера. Санкт-Петербург: «Искусство-СПБ», 400-425.

- 2004b. = Лотман, Ю. М., О двух типах ориентированности культуры. Семиосфера. Санкт-Петербург: «Искусство-СПБ», 425-427.

— 2004c [1973]. = Лотман, Ю. М., Миф - имя - культура (совместно с Б. А. Успенским). Семиосфера. Санкт-Петербург: «Искусство-СПБ», 525543.

— 2004d [1978]. = Лотман, Ю. М., Феномен культуры. Семиосфера. СанктПетербург: «Искусство-СПБ», 568-580.

- 2004е. = Лотман, Ю. М., Асимметрия и диалог. Семиосфера. СанктПетербург: «Искусство-СПБ», 590-602. .

- 2004f [1989] = Лотман, Ю. М., Культура как субъект и сама-себе объект. Семиосфера. Санкт-Петербург: «Искусство-СПБ», 639-647.

Norval, Aletta J. 2004. Hegemony after deconstruction: The consequences of undecidability. Journal of Political Ideologies 9(2): 139-157.

Sandel, Michael 1998. Liberalism and the Limits of Justice. Cambridge: Cambridge University Press.

Schönle, Andreas (ed.) 2006. Lotman and Cultural Studies. Encounters and Extensions. The University of Winsconsin Press.

Steedman, Marek 2006. State power, hegemony, and memory: Lotman and Gramsci. In: Schönle (ed.) 2006: 136-158.

Žižek, Slavoj 1989. The Sublime Object of Ideology. London: Verso.

Walzer, Michael 1984. Spheres of Justice: A Defence of Pluralism and Equality. New York: Basic Books. 


\section{К проблеме семиотической теории гегемонии: называние как «гегемоническая операция» у Юрия Лотмана и Эрнесто Лакло}

Настоящая статья явлется попыткой спровоцировать диалог между двумя разными теоретическими системами концептуализации социальной реальности и власти: это теория гегемонии Эрнесто Лакло, одного из ведущих современных ученых в области политической теории, и семиотико-культурологический подход Юрия Лотмана. Более отдаленная цель - выработать концептуальные средства для более ясного освещения соотношения между социальной реальностью и властью. Несмотря на различия в плане выражения этих двух авторов, мы видим в их разработках существенные содержательные и функциональные точки пересечения: понятие границы, антагонизм, называние и т. п. В данной статье мы сосредоточиваемся на функции номинации в процессе конструирования политической реальности. Мы предлагаем возможность замены некоторых главных теоретических категорий Лакло категориями семиотики культуры Лотмана. Это позволило бы лучше эмпирически изучать стратегии конструирования социальной реальности и избегать привнесения психоаналитических трактовок, характерных для поздних работ Лакло.

\section{Semiootilise hegemooniateooria poole: nimetamine kui hegemooniline operatsioon Lotmanil ja Laclaul}

Käesolev artikkel on katse arendada dialoogi kahe erineva teoreetilise lähenemise vahel - need on kaasaegse poliitilise teooria ühe juhtiva teadlase Ernesto Laclau hegemooniateooria ning Juri Lotmani kultuurisemiootiline lähenemine - mille kaugem eesmärk oleks välja töötada kontseptuaalsed vahendid hõlmamaks selgemini sotsiaalse reaalsuse ja võimu vahekordi. Hoolimata nendevahelisest verbaalse väljenduse erinevustest, näeme nende käsitlustes olulisi sisulisi ja funktsionaalseid lõikumispunkte - piiri mõiste, antagonism, nimetamine jne. Antud artiklis keskendutakse nimetamise funktsioonile poliitilise reaalsuse konstrueerimisel. Me pakume välja võimaluse asendanda mõned Laclau peamised teoreetilised kategooriad Lotmani kultuurisemiootika kategooriatega. See võimaldaks paremini uurida empiiriliselt sotsiaalse reaalsuse konstrueerimise strateegiaid ning vältida psühhoanalüütilise käsitluse sissetoomist, mis on Laclau hilisematele töödele omane. 
